S. CEČUK:

\title{
PRLOG POZNAVANJU SORTIMENTA PODLOGA U VINOGRADARSTVU HERCEGOVINE
}

\begin{abstract}
Sadrz̆aj̃: Uvod - Današnje stanje vinogradlarsklh podloga. Saviemeni kruterij odabiranja "podıga. - Kritlčki osvrt na postojece podloge. - Preporuka perspektivnog sortimenta podloga. - Zaključak.
\end{abstract}

\section{U vod}

Najkrupnija greška koju može vinogradar da počini prigodom podizanja novog vinograda na amerikanskim pudlogama, jest: loš izbor podloga.

Od pravilnog izbora podloga zavisi ne samo stalna rodnost, kolicina i kakvoća proizvoda, nego i dugotrajnast života posađene loze. Prema tome, pravilan ili nepravilan izbor podloge za odredeno zemljište, $u$ određenom klimatu, sa određenim ekonomskim ciljevima proizvodnje, od presudnog je značaja za vinogradare koji podižu ili obnavljaju vinograde.

Budući da je loza vrlo skupa, višegodišnja 1 intenzivna lkultura, potrebno je temeljito razmisliti kako pristupiti izboru najprikladnijib podloga u pretstojećoj drugoj obnovi vinograda u Hercegovini, naročito zato što ni do danas nismo zaboravili na teške posljedice pogrešno izabrane podloge Aramon $\times R$ upestris Ganzin br. 1 priliksom prve obnove vinograda $u$ Dalmaciji i Hercegovini (1) niti smo se od njih oporavili.

\section{Danas̆nje stanje vinogradarskih podloga u Hercegovini}

Po završetku Prvoga svjetskoga rata, pristupilo se prvoj obnovi vinograda u Hercegovini. U prvim potecima sadilo se bez iskustva do čega se došlo. $O$ izboru podloga malo se znalo.

U vremenu od 1920 do 1928 godine, za vrijeme prve obnove hercegovackih vinograda na amerikanskim podlogama, bile su uvedene (iz Cibace preko rasadnika Ljubuški) slijedeće podloge:

Aramon $\times R$ upestris Ganzin 1

Rupestris du Lot

Solonis $\times$ Rupestris Pecs 1

Mourvedre $X$ Rupestris 1202 Couderc Nešto kasnije:

Riparia $X$ Rupestris Schwartzmann Godine 1928: 
Riparia $\times$ Berlandieri Kober $5 \mathrm{BB}$ i Teleky $8 \mathrm{~B}$, te Godine 1947:

Riparia $\times$ Berlandieri 420 A $M \& G$

Ovaj broj podloga mogao bi zadovoljiti potrebe i najrazlicitijih lipova vinogradarskih tala Hercegovine, pod uslovom da se svakoj od pudloga tučno agroekološki odredi pravo mjesto. Ali nije st znalo, kao što se ni danas dovoljno ne zna, koje su i kakve podloge potrebne vinogradarstvu Hercegovine u odredenim mikrorejonima, za specificki odredene ciljeve proizvodnje. Kompleksna problematika hercegovačkog vinogradarstva nije sistematski proudavana, pa se pristupalo i još se pristupa proizvoljnom izboru podloga, bez prethodno ispitanih uslova. Do pojave fijoksere na evropskoun kontinentu polovinom proslog stoljecia problem podloga praktički se u vinogradarstvu nije uopce poslavljao.

$\mathrm{Na}$ osnovu $\mathrm{L}$ a li manovih zapažanja da neke amerikanske loze ne stradaju od uboda filoksere, dok je evropska loza posve neotporna, $G$. $\mathrm{Bazi} \mid \mathrm{l}$ e je predjožio na vinogradarskom kongresu u BCa une 1869 kalemljenje domace pitome loze na amerikansiku divlju lozu kao izloz iz filokseriene krize (2). Otada pa do danas pilanje izbora podloga postalo je i ostalo osnovno pitanje rekoristrukcije filokserienih vinograda. Genetičari nisu uspjeli da putem direktnorodnih hibrida dodu do toliko priželjkivane idealne loze, "koju ne bi trubalo kalemiti niti prskati ili prašiti raznim fungicidima i insekticidima, a koja bi rađala kvalitetno grozđe ij davala kvalitetno vino.

Do toga sretnog otkrica madalje ce se tragati za izborom najprikladnijih podloga na kojima ce se i nadalje klasiłnim metodama kalemljenja, obnavljati naši vinogradi $(3,4,5)$.

Međutim, problem podioga komplicira se time sto se medu stotinama isprobanih podloga pronađu neke, vrlo padesne za izvjesino vrije me, da zatim najerlnom, iz još nedovoljno objašnjenih razloga, poenu da nazaduju i konačno propadinu.

Kao primjer služi nam propadanje podloge Aramon $\times R$ un pestris Ganzin 1.

$\mathrm{Na}$ ovoj je podlozi sa uspjehom bila izvræena prva obnova vinograda u Dalmaciji sa preko $60 \%$, a kasnije i u Hercegovini sa punih $25^{n} / 4$. $\mathrm{Me}^{-}$ đutim, ova je podloga posve zatajila i iz vinogradarske prakse a Dalmaciji i Hercegovini isključena, mada je u svaje doba slovila kao najorniljenija porloga i vrjicdila kao univerzalna (6).

U Francuskoj dosadal vodeća podloga $R$ upest $r$ is $d u$ Lot, već se postepeno napušta, jer je postala vrlo osjetljiva na infektivnu degęneraciju (7).

U Makarskom primorju i Sinjskoj Krajini toliko hvaljena podloga Riparia $\times$ Berlandieri Kober 5BB peinje da propada ("svrče kalemove, propada od suše :. ugušenja«). I u Vojvodini S. M a tek o v ić izvjestava (8): "Poznat je već jedan slučaj da su se u mladom vinogradu kalemljenom na podlozi $\mathrm{K} \circ$ b er $5 \mathrm{BB}$ pojavila mjesta gdje cokoti propadaju u obliku »gnezda", na koji su način u godinama pre rata u velikom obimu propadali naprimjer vinogradi kalemljeni na $P$ or t a $l$ isk.

Dok se to zbiva sa podlogom Kober $5 B B$ u nasoj zemlji, dotle neki vinogradarski struěnjaci vele za Kober $5 \mathrm{BB}$, da je kao podloga dala iz- 
vanredne rezultate ne sumo u Hercegovini nego i u Vojvodini, Rusiji i Armeniji, pa je preporučuju za »univerzalnu podlogu« $(9,10)$.

\section{Savremeni kriteriji ocjenjivanja (odabiranja) podloga}

Dok smo u prvoj obnovi vinograda u našoj zemlji, pa i u Hercegovini, pristupali skoro stihijski, nemajuci nekog narokitog iskustva o podlogama, dotle se u započetoj drugoj obnovi vinograda u Jugoslaviji, pa i u Bosni i Hercegovini, mora pristupati sa više opreza, jer se danas postavljaju mnogo teži i brojniji zahtjevi pri izboru podlogia nego što je to bilo kod prve regeneracije.

U prvoj obnovi vinograda, prvenstveno se tražilo svojstvo što boljeg sljubljivanja plemke sa podlogom, tzv. afiniteta, ili što bolje kompatibilnosti izmedu kalemljenih bionata da gotov kalem (navrnuta loza) postane što idealnija simbiotička cjelina, tj. novi sjedinjeni jedinstven organizam kod kojeg ce podloga (hipobiont) cavati navrtku (epibiontu) svu potrebnu mineralnu hranu iz tla, a Navrtak podlozi asimilate iz procesa fotosinteze. Cim na zoni spajanja navrnutih bionata bude postojala bolja botaniłka srodnost, jednaka bioloska starost i što bolja kompatibilnost anatomsko-histoloskih elemenata, tim ce harmonija intercelularnog metabolizma na spojnom mjestu biti potpunija, time i uspjeh kalemljenja sigurniji. Stvaranje guke (baražne prepreke) na spojnom mjestu i velicina te guke, odraz je stepena srodnosti izmetu simbionata. Ako su simbionti podjednake bujnosti tj. adekvatnog vegetativnog potencijala i pozitivne kompatibilnosti, baražna ce guka na spojnom mjestu biti tim neznatnija. Protivno, guka je tim veća što je veća razlika vegetativnog potencijala između sirnbionata (11).

Budući da je u prvoj obnovi vinograda u Jadranskom vinogradarskom rejonu, naročito u Dalmaciji i Hercegovini, isključivo primjenjivaua metoda zelenog kalemljenja (na mjestu u vinogradu), a podloga A r amon $\times$ Rupestris $C_{1} l$ je pokazala u tom pogledu najbolja svojstva sljubljivanja í sa najrazličitijim sortama domace (pitome) loze, jasno je da je ova podloga zauzela prvo i vodece mjesto u prvoj obnovi vinograda Dalmacije (12) (od 1900-1930), a u Hercegovini od 1913-1934 godine.

Pri tadašnjem ocjenjivanju izbora podloga težište se stavljalo na svojstvo afiniteta, tj. da je podloga dovoljno wbujna: i da dobro prima zeleno navrtanje. Ovo se iskljuçivo forsiralo i sa službene strane stimuliralo pomaganjem osnivanja suzornih vinograda ("Musterpflanzungen «). Posve, ili skkoro posve, zanemarivani su ostali važni zahtjevi koje treba da ispuni dobra podloga: prvenstveno da je dovoljno otporna prema ubodima filoksere i da se clobro prilagođava raznim vrstama tala. Međutim ova dva svojstva: otpornost prema filokseri i prilagođenost prema thu nisu pravilno uzimana u obzix, ma da su od velike važnosti (13).

Danas, $u$ drugoj obnovi vinograda, svojstvo otpornosti prema filokseri ne zadaje nam brige pri izboru podloga, jer imamo u praksi dovoljan broj prakttčki otpornih podloga prema ubodima filoksere kao takvih, ukoliko se naime, ne dokaže da je ona prenosilac infektivne degeneracije. Isto tako i problem izbora podloga s obzirom na sadržaj kreča it tlu (svojstvo prilagođivanja) nekad, u prvoj obnovi nadasve težak za 
datak, olakšan je otkako je u novije doba pronađena analiticka metoda određivanja fiziološki aktivnog kreča w tlu po Drouineau-Galetovoj me* todi (14).

Inače se ranije, od prve obnove vinograda pa do 1950 godine određivao sadržaj ukupnog kreča (karbonata) po klasičnim kalcimetrijskim metodama Bernarda ili Scheiblera, po kojima se nije moglo nî sa približnom sigurnošću odabrati odgovarajuce podloge, jer su se u praksi susretali sluđajevi žutikanja (kloroziranja loza) na tlima sa relativno malim sadrźajem ukupn hh karbonata, dok su na drugoj strani, te iste podloge uspijevale i. na tlima sa velikim sadržajem ukupnog kreč. Mader (15) izvještava o Koberovim zapažanjima, po kojima je npr. Riparia Gloire de Montpellier, koja je dosta asjetljiva na veće količine krexa (podnaša do $12 \%$ ) uspijevala odlično na thu $76 \%$ $\mathrm{CaCO}_{3}$ dok je na drugom thu sa samih $4 \% \mathrm{CaCO}_{3}$ bila potpuno klorotiena.

Od drugih stetnih sastojaka kojih se ponekad nade u tlu a u vezi svojstva adaptacije podloga, dolazi natrijev klorid ili morska so. Na slatinama ili na ušcima rijeka, gdje dolazi podzemna morska voda u doticaj sa korjenovom mrežom loza (naročito za vrijeme ljetnih suša kad koncentracija $\mathrm{NaCl}$ postaje nepodnošljiva za većinu podloga), za okvakva tla treba birati podloge koje su otporne prema takvim zaslanjenim tlima. Za ovakva tla najbolje su u praksi: Solonis $\times$ Riparia $1616 \mathrm{Co-}$ uderc i (nešto slabije) Solonis X Rupestris du Lot 216-3 Cl ili Pecs 1 (16).

Osim ovih triju primarnih faktora (otpornosti, prilagodivanja i sljubljivanja), danas se pri izboru traže jos: otpornost podloga prema suši (za Hercegovinu cd primarne važnosti, jer je svaka treća godina u pravilu sušna); otpornost podloge prema preobllju vlage, sto je od posebnog značaja za nizinskka vinogradarska staništa (Popovo polje, Mostarsko blato, Deltza Neretve i sl.); dobro oživljavanje I ukorjenjavanje (svojstvo iwoje naroxito dolazi do izražaja kod Berlandieri hibrida); dobro reagovanje podloga na ampelotehniku; od posebnog je znacaja u najnovije doba otpornost (reagovanje) podloga na finalne vinogradarske proirvode tj. na kvalitet i kvantitet grožđa i vina.

S obzirom na vrlo ceste suse u Hercegovini i na njihove štetne posljedice, problem od̉nosa podloga prema suši izbližeg sam promatrao tokom ljeta 1954 u juznoj Francusiroj. Tamo su se u slixnim agroekoloskim i pedoloskim prilikama kao i u Hercegovini, za najsušnije 1949 godine pokazall prema suš relationo najotporniji Malegue-ovi trihibridł CorAifolia-Rupestris $\times$ Rupestris-Riparia, dok su najslabiju otpornost pokazali Riparia $\times$ Rupestris hibridi (17). 
S K A L A

relativne otpornosti podloga prema susi u odnosi na Rupestris du Lot ${ }^{3}$ ):

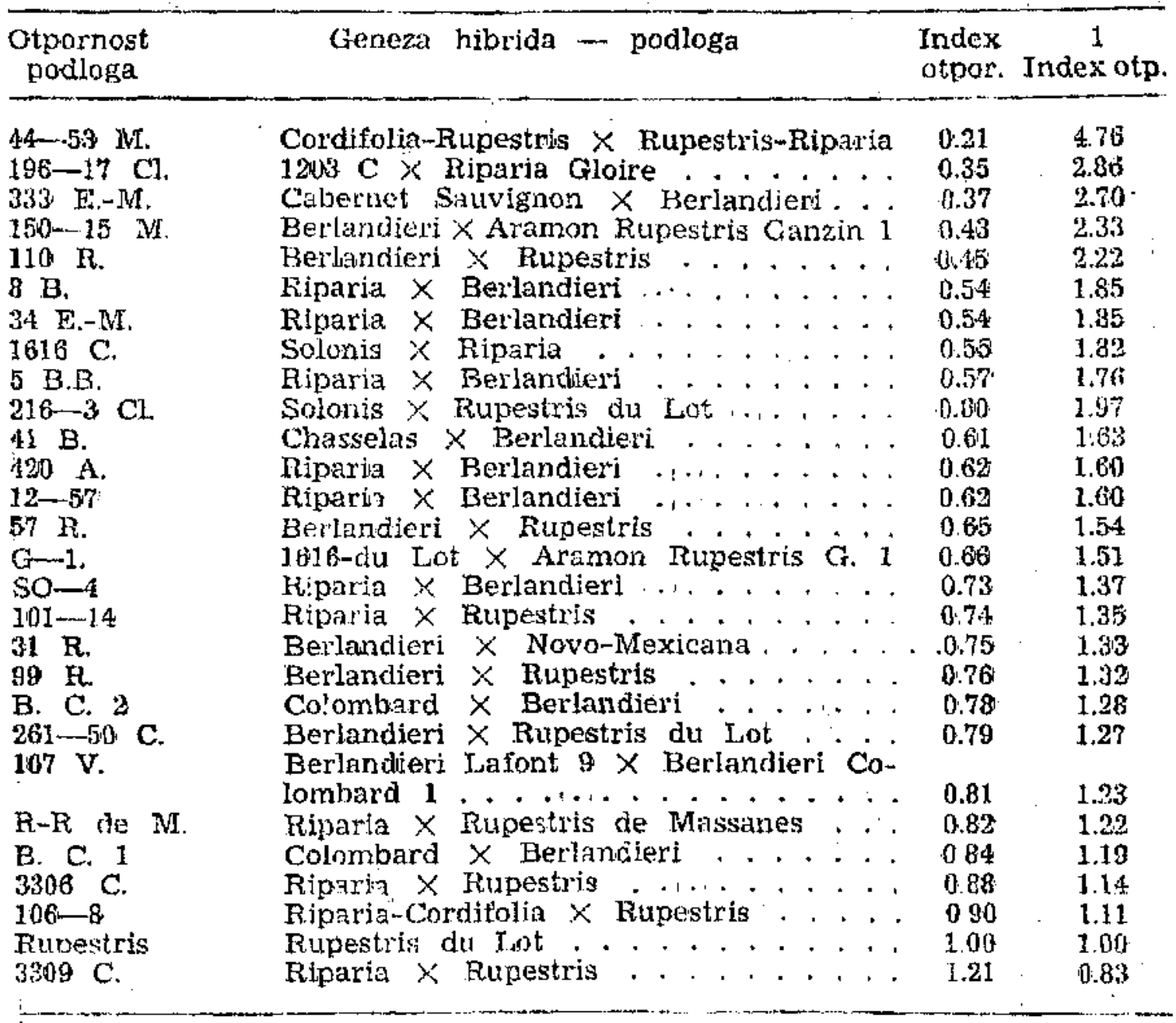

U uslovima preobillia vlage preporučuju se one poñloge koje imaju veći ?kut geotropizma, odnosno podloge $s a$ horizontalnim rasprostivanjem korijenova mreže. Tu dolaze u obzir: Riparia Portalis (Gloire de Montpellier) i Solonis XRiparia 1616 (18).

Nedostatak ožiljavanja pokazuju Berlan d ieri podloge u nčistoj krvik, a i nekoji njihovi hibridi. Najbolje ožiljavanje u ovoj grupi B erlandieri hibrida pokazuje Berlandieri $X$ Riparia 169-41 $\mathrm{C}(19)$.

Prema infektivnoj degeneraciji nema apsolutno otpornih podloga (20) ali se do danas $u$ praksi pokazuju relatiwno kao najotpornije $R$ upestris $\times$ Berlandieri 110 i Riparia $X$ Berlandieri $161+49$.

U pogledu kvalitetne ili kvantitetne proizvodnje grožđa - vina, a u vezi izbora podloga, uvijek još vlada vinogradarski princip da za kvantitetnu proizvodnju biramo bujnije podloge, a za kvalitetnu podloge slabiite bujnosti, uz pretrostavlsu da se ekonomski ciljevi proizvodnje poklapaju sa agro-ekološlkim uslovima određene sredine.

*) Po Boubals-u : 1: Huglin-u (17). 
Zbir gore navedenih faktora $u$ vezi izbora jedne ili vise podloga, mora da se optimalno slaze i sa ciljevima proizvodnje sa prirodnim uslovima odredene sredine odnosno sal zahtjevima odredene sorte.

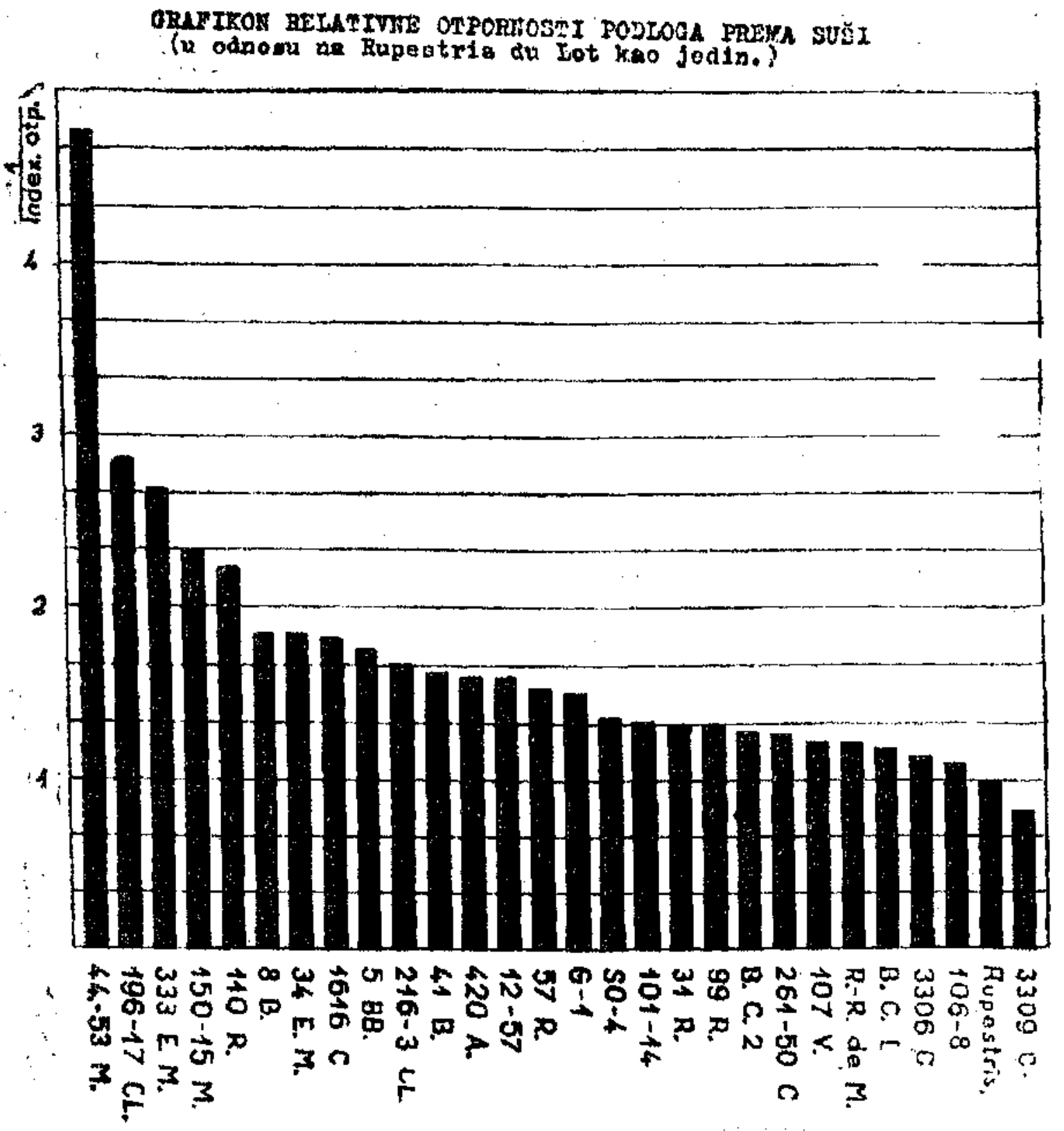

Kriticki osvrt na postojecé stanje vinogradarshih podloga u Hercegovini

Pri drugoj obnovi vinograda treba poći sigurnijim putem i uz potreban oprez, jer podizanje vinograda koliko je ekonomski vrlo skup pothvat toliko je vrlo složen problem, a postaje iz dana u dain još složenijj zbog pojave infektivne degeneracije, afiniteta $\mathrm{i}$ dr., pogotovo kad drugoj obnovi vinograda pristupamo bez temeljitijega prethodnog rada, kao u Hercegovini. Ali kako vrijeme ne ¿eka, monamo se zadovoljiti dosadasnjim vlastitim i stranim iskustvima, vjerujući da će manje stete biti od eventualnih grešaka, negu sto bi ih bilo od dugotrajnog cekanja i provjeravanja rezultata istraživackog rada na ovom polju. 
Danas u Hercegovini, kad vec imamo gotovo tridesetgodišnje iskustvo sa prvotno uvedenim podlogama, ne bi bio odviše težak izbor podloga u postojećim prilikama proizvodnje-vina. Ali perspektivno, u uslovima planske proizvodnje tipiziranih vina $̌$ i l a $v \mathrm{k}$ e $\mathrm{i}$ B la tin e i proizvodnje ranoga stonog grožđa i suhvica, bez obavljene vinogradarske mikrorejonizacije, i bez obavljenog pedološkog kartiranja, teško je odrediti odgovarajući izbor podloga i odrediti njihov međusobni procentualni odnos.

Radi orijentacije (i eventualne diskusije) dacemo ovdje samo osnovne smjernice i principe za izbor podloga. U svakom konkretnom slučaju, prije podizanja vinograda na određenom vinogradarskom staništu morace da se izvrł̌ pedološlza analiza odnosnog tla, naročito s obzirom na sadržaj fiziološki aktivnog kreča.

Ako je ekonomski cilj da se proizvode obična masovna jeftina stolna vina putem plantažnih vinograda (a agroekolobłki i pedološki uslovi to dozvoljavaju), uzimaju se bujne podloge i na njima kaleme-dobre rodne domace evropske sorte loze (V. Vinifera L.), jer to osigurava kvantitet.

Za ovakav tip proizvodnje treba u Hercegovini uzimati podlogu: Rupestris du L ot (tzv. Montikolu). Međutim, to se prigodom prve obnove vinograda u Hercegovini sigurno nije znalo. Otuda i podvojenost misljenja o valjanosti ove pordloge. Kude je oni koji ne poznaju njena gospodarska svojstva i biološke osobine, a hvale je oni koji su "sretnim slučajem « pogodili njeno pravo mjesto u odnosnom vinogradarskom. staništu.

Po dosadašnjim domaćim i strianim iskustvima ova je klasična podJoga još i ranas najzastupljenija na području mediteranskog bazena u Francusikoj i Sjevernoj Africi (21), kod nas (22), na Siciliji (23) i u Burarskoj (19).

Ova podloga ima slijedece prednosti: Odoljava dobro filokseri, klorozi. i suši. Zadovoljava se i mršavijim, slabo plodnim, sadrastim, supljikavim, dubokim, pješčanim tlima. Ne traži dubrenja ili ga traži u manjoj mjeri, a pozitivno utice na povišenje rodnosti i na dozrijevanje kasnih stonih sorata grožđa. Obzirom na povoljan indeks (fizioloski aktivnog kreča po Gra let-u do $14 \%$ ) (14), ova bi podloga time stekla pravo i na dalju rasprostranjenóst. Ali je krupni nedostatik ove podloge sto sve više podliježr infektivnoj deǵeneraciji zbog koje se grožde osiplje, pa se zbog toga ova podlogga sve više napušta na zernljištima zaraženim od Courtno u e-a (24). Ostali nedostaci, koje joi mnogi pripisuju, odnose se na nepoznavanje njenih zahtjeva na tlo, ishranu, klimu, sortu-epibiont i njene zahtjeve na ampelotehniku (s osobitim obzirom na dubriva $i$ rezidbu).

Srećom danas raspolažemo u vinogradarskoj praksi jednom mnogo holjom podlogom nego što je i sama Rupestris du Lot u »čistoj krvi«. To je njen potomak: hibrid, plod ukrštavanja Berlandieri sa $R$ upestris Martin, to jest:

\section{Berlandieri $X$ Rupestrís Richter 110}

Svagdje gdje je dosad Rupestris du Lot dala dobre rezul tate, na istim stanistima, uz jednake ekonomske ciljeve proizvodnje, dala 
jẹ čak i bolje Berlandjeri $\times$ Rupestris 110. Osobine su ove podloge: Podnosi vece kolixine ukupnih karbonata (do $40 \%$, a fiziološki aktivnog do $17 \%$; dok R u pestris du Lot podnasa do $35 \%$ ukupnih Karbónata i $14 \%$ fizioloski aktivnog krexa), Bolje odolijeva sušl i na plicim terenima nego Rupestris du Lot. Prima bolje kalemove ina stalnom mjestu u vinogradu, Utǐe na bolju i stalniju rodnost, a ne rehulja kao $R$ upestris du Lot. S obzirom na sva ova preimućstva, kao i na tinjenicu da se ova podloga dosad pokazala relativno kao najotpornija i prema infektivnoj degeneraciji, veoma je eijenjena od južnofrancusikh i sjeveroafričkih vinogradara. Moje 15-godisnjue iskustvo u praksi, sa ovom podlogom u Dujmovači-Solinu (kod Splita) potvrđuje nabrojane prednosti ove, rekao bih, najbolje savremene podloge; lao zamjene za $R$ upestris du Lot, pod uslovom da zaista dode u odgovarajuću agroẹkološku sredinu, i da se na nju kaleme odgovarajuće domaće kvantitetne sorte. Kod mene je dala odliěne rezultate sa Smederevkom i Trbljanom.

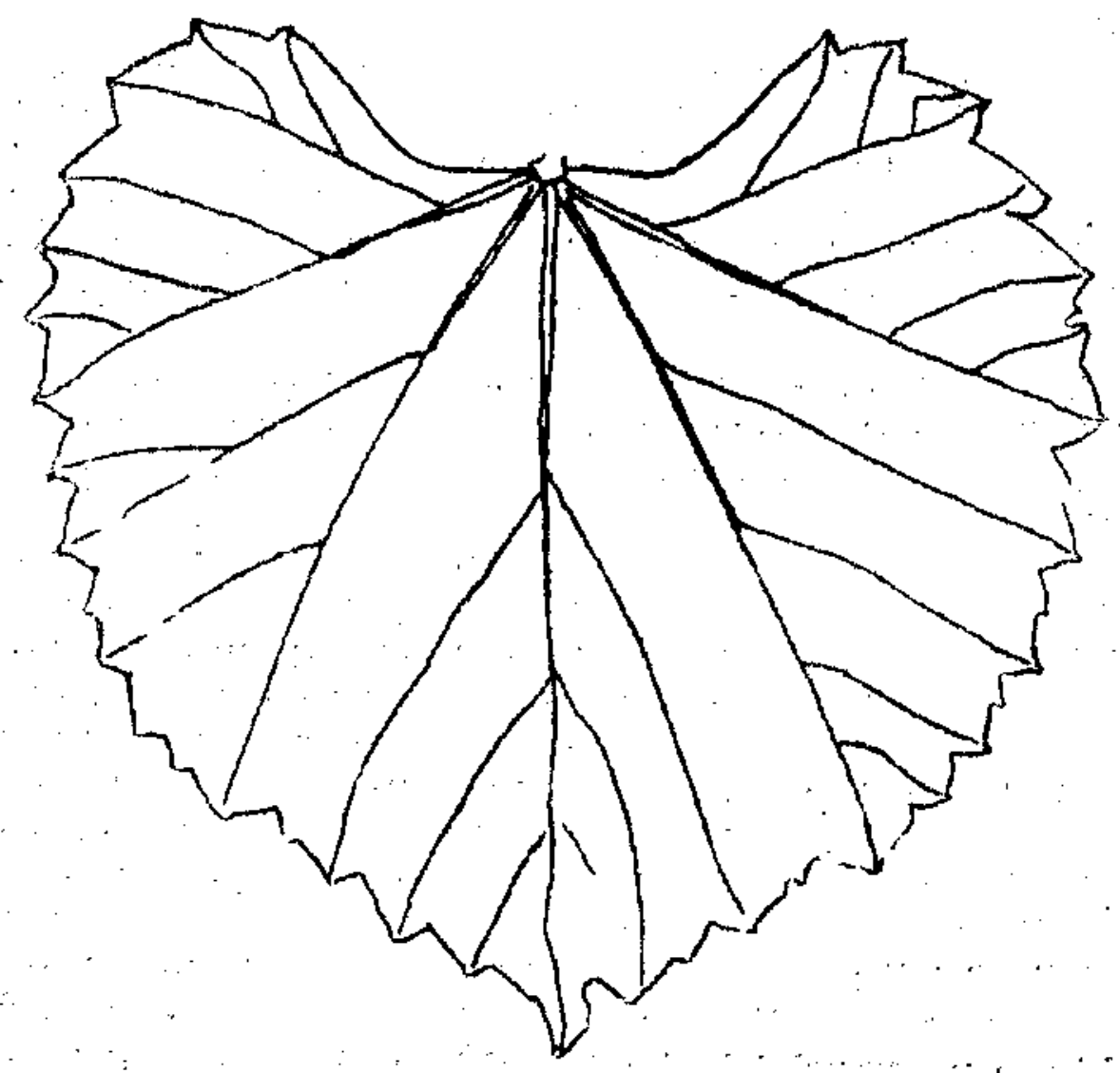

S1. 1 .... 110 Richter

.. Ovoj podlozi francuskog porijekla, uzgoja $\mathbb{R}$ ichter, najblizi su srodnici "po krvi« hibridi talijanskog porijekla $R$ ug geri (140) i $\mathrm{Pa}$ u lsen $(1103,1447$ i dr.). Ove su podloge takoder dale zadovoljavajuće rezultate, koliko u prinosima toliko i u velikoj otpornosti prema klorozi i suši. Postojl brojna dokumentacija o provjeravanju sa Sicilije i Sjeverne Afrike, gdje su ove podloge stekle pravo zavicajnostl, a takoder 1 kod fias iz pokusnog nasada u Dujmováci kod Solina. 
Ako je ekonomski cilj da proizvodimo kvalitetnija buteljska vina áli stono gožđe, a agroekološki i pedološki uslovi to dozvoljavaju, biracemo podloge srednje bujnosti i na njih kalemiti odgovarajuće domaće sorte srednje rodnosti da tako obezbjedimo kvalitetnu sirovinsku bazu.

Po dosadašnjim iskustyima, za ovo su bile najbolje podloge:

Berlandieri $\times$ Riparia Kober 5 BB i Berlandieri $\times$ R iparia 8 za krečna tla u Hercegovini, a $R$ iparia $X R$ upestris Schwartzmann za crvenice.

Preovladava mišljenje da su sve ove tri podloge dale dobre rezultate u vinogradima Hercegovine. Staviše, neki autori za Kober navode (9) da je dala izvanredne rezultate, wda je po svojim svestranim svojstvima najbliži idealnom, dakle univerzalnom tipu podloga

Poznati švicarski vinogradarski stručnjak Dr. Fa es već je davno rekao: "Nema univerzaine loze (podloge), veé svaki vinogradarski kraj mora na osmovu brižljivih pokusa pronaći najbolju podlogu «. O univerzalnoj upotrebi jedne podloge $\mathfrak{u}$ postfilokserionom vinogradarstvu ne može se ni pomišljati, jer smo svjedoci propadanja negdašnje suniverzalnex podloge A ramon.

Sto se tice zahtjeva podloge Kober $5 \mathrm{BB}$ u uporedenju s Telek $i$ $8 \mathrm{~B}$, ova druga je po mojem višegodišnjem posmatranju u Dujmovači, daleko skromnija od Kobera, naroxito u pogledu dubriva. Zato smatram da bi za hercegovačke prilike bila više na mjestu upotreba $T$ ele $k \mathfrak{i}$ podloge (nakon odabiranja najboljeg tipa) nego Kobera. Takvog je miłljenja bio i $S$. Ma te k ović (8) prilikom savjetovanja vinogradarskih strucnjaka u Zagrenu 1953 , pa se ne bih mogao složiti sa navodima $M$. Jela ske (22) nda je prema dosadašnjim iskustvima Kober 5 BB bez sumnje vrednija podloga od Telekijevi hrižanaca $8 \mathrm{~B}$ «.

Sto se tiče podloge $R$ ip aria $\times$ Rupestris $S \mathrm{ch}$ wartzmann, kojom se misli da zamijeni podlogu Aramon $X$ Rupestris Ganzin 1, koja propada, mislim da ni to nije sretno rješenje za prilike Hercegovine iz razloga koji ce biti dalje u tekstu navedeni.

Naime, ako se kritički osvrnemo na sve tri dosadašnje hercegovačke podloge: Riparia $\times$ Berlandieri Kober 5 BB Teleki 8 B, i Riparia $\times R$ R pestris $\mathrm{Sch}$ artzmann, prigovara se svima trima da ne podnose previše suva, mršava i plitka tla, a Schwart$z \mathrm{~m}$ a n n ni krečna tla. Sve ove tri podloge traže dobra, plodna, dubaka zemljista, primjernu agrotehniku (obradu) i stalno izdašno dubrenje, inače nazaduju. Postavlja se pitanje da 11 su svi ovi zahtjevi prakticki u vinogradarstvu Hercegovine ostvarljivi. Ja mislim da nisu. Zato u drugoj obnovi vinograda treba poseći za boljim, prikladnijim, vitalnijim podlogama, kad vec takve postoje, koliko zbog pedološke heterogenosti hercegovačkih tala, toliko i zbog aridnosti hercegovačke klime, ne zaboravljajuci pritom ni na stvarne mogućnosti primjene naprednije ampelotehnike kod hercegovaǔkih vinogradara.

\section{Predlog perspektivnog sortimenta podloga za Hercegovinu.}

U zamjenu za Rupestris du Lot predložena je podloga Rictit er 110 iz naprijed objašnjenih razloga. U zamjenu za Kob e r 5 BB Tele $\mathrm{k}$ i $8 \mathrm{~B}$ predlaže se za Hercegovinu Ku de $\mathrm{k}$ ov hibrid: Ri par $\mathrm{Ka}$ 
X Berlandieri 161-49, a mjesto Schwartzmanna, Malegor trihibrid: Riparia Grande G1abre Rupestris du Lot Cord if oli a 44-53.

\section{Riparia $\times$ Berlandieri 161-49 Couder}

Ovaj inače stari hibrid (koji je C ou d e r c uzgojio jos 1888 u Aubenas-u, Francuska) došao je poslije više decenija na poprište kao najnoviji. favorit $i$ danas je najviše tražena podloga ove vrsti $u$ Francuskoj, klasienoj zemlji vinogradarstvia, a isto tako i u drugim vinorodnim zemljama oko Sredozemlja.

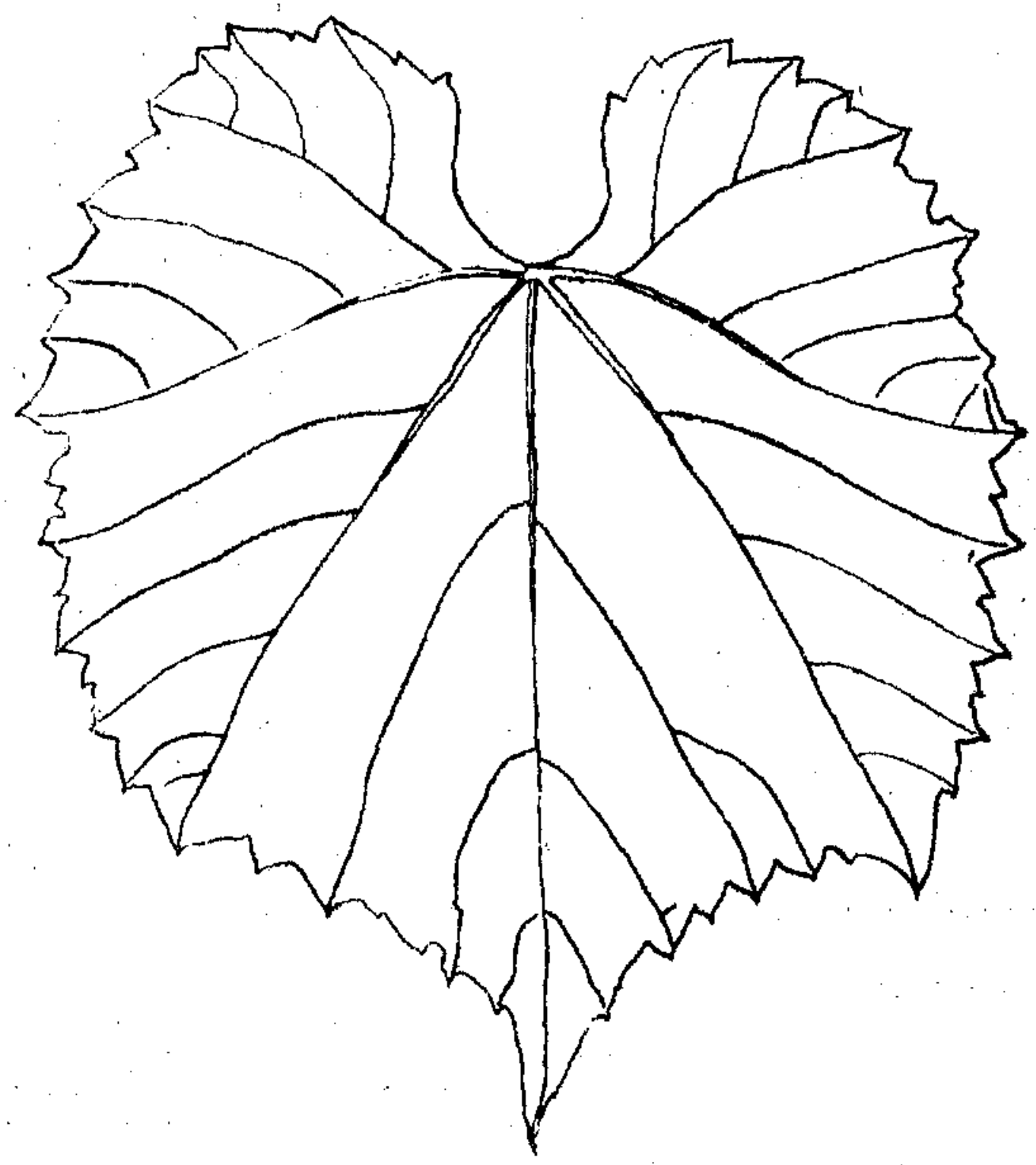

S1. $2-161-49$ Coudere

Prednosti su ove podloge: Tlo ne bira (5). Ima dobro ożiljavanje odnosno primanje pri sadnft (19). Utice povoljnije na rodnost i dozrijevanje grožđa (po Dümmler-u). Upotrebljava se kao podloga za rano grožđe i projzvodnju kvaljtetnijih vina. Podnosi suha i zblta tla sa velikim 
sudržajem ukupnog i fiziološki aktivnog kreča (do 60\% ukupnog i 25\% fiziološki aktivnog), pa dolazi odmah poslije Chasselas $\times$ Berlandi e $\mathrm{r}$ i $41 \mathrm{~B}$ kao najotpornija podloga prema kreču. Ova se podloga preporučuje za sorte koje rehuljaju, pa ce u Hercegovini naročito dobro doći za blatinu, krkkošiju i pošip. U Francuskoj je ova podloga postala naročito traženom, jer se pomoću nje, po izjavama francuskih vinogradara, navodno, najlakšs mogu da obnove vinogradi koji su zaraženi od infekm tivne degeneracije iako time nije rečeno da je ova podloga otporna prema intektivnoj degeneraciji. Ovo je sva tajna, zašto ova podloga ima svjetar u karmu« (25), tj. zašto je vrlo tražena, a zna se kakvu muku muče francuski vinogradari sa bolesnom pojavom Courtnouema na lozama, sa kojom éemo i mi imati u skoroj budućnosti sigurno glavobolju. Jedino se prigovara ovoj podiozi da kalemljena. izvjesnim evropskim sortania (u prvim godinama) navodno trpi od sapoplexije: (26).

$\mathrm{Za}$ vinogradarska staništa s velikim sadržajem fizioloski aktivnog kreča treba ubuduće podizati vinograde sa podlogom: Chasselas $X$ $B$ e rl a n d jer i 41 B M \& G. Ova je podloga omogućila obnovu vinograda na veoma vapnenim tlima Sampanje i Sarante (u Francuskoj), na kojima izdrži i do $70^{\circ} \%$ ukupnog i $40^{\%} \%$ fizioloski aktimog kreèa, a kod nas je u Makedoniji dala najbolje rezultate.

Na mjesto toliko diskriminirane podjoge Ar a mon $\times \mathbb{R}$ upestris Ganzin 1 , pa hirovite po zahtjevima $u$ pogledu dubriva Riparie $X$ Rupestris Schwartzmann, ubuduće bi mogao doc̀i u Hercegovinu Malegov trihibrid: Berlandieri $X$ Aramon $X$ lupest. $r$ is $G$ 150-15 M. Ova podloga svojom bujnosću, primanjem kalemova i modnosti ne zaostaje ni po čemu iza bivš stare podloge $A$ s'am on $\chi$ $\mathrm{R}$ upestris G 1. Donosom wrvik Berla st ieri ova podloga postala daleko otporisijom. prema kreču od starog Aramona. Vrlo je otporna prema suši i dalcko otpomija prema filokseri od bivšeg Aramona.

Za hercegovačk crvenice (terre rosse), umjesto dosadasnje $R$ i p am ria $\times$ Rupestris Schwartzmann, trebalo bi preporučiti, takoter rovog favorita vinogradarstva, podlogu:

\section{Riparia Grande Glabre-Rupestrị du Lot $\times$ Cordifolia 44-53 Malegue}

Ova podloga ima brojne vrline koje zasjenjuju podlogu $R$ ip a ria $X$ Rupestris Schwartzmann. Prednosti su ove podloge: Vrlo je otporna prema suši. Odlično se ožiljava i odližno prima pri sađenju. Lako prima kalemove. Podnosi do $28 \%$ ukupnog i do $11 \%$ fizioloski akmtivnog kreča. Naročito tumanjuje rehuljavost domaćih sorata loze sklonih rehuljanju (bas kod nas slucaj blatine, krkosije, pošipa i dr.). Ova je podloga vrlo dobro prilagodena ne samo za crvenice, nego takoder za pjeskovita tia i žalike, dakle za mršava tla na kojima $\mathrm{R}$ i.pa $\mathbf{r}$ ia $\times \mathrm{R}$ upestris Sehwartzmann zataji. Opcenito, ova podloga utǐe pozitivno na rodnost. Interesantno je da se napomene za ovu podlogu da zimi podnosi velike kolicine vlage, a ljeti opet stoji na celu najotpornifih podloga prema suši (17). 
Za naslana tla (kojih zapravo u Hercegovini skoro i nema) ostaju i nadalje kao najbolje podloge Sol on is X R iparia $1616 \mathrm{C}$ i Solon is Rupestris du Lot 216-3 C 1.

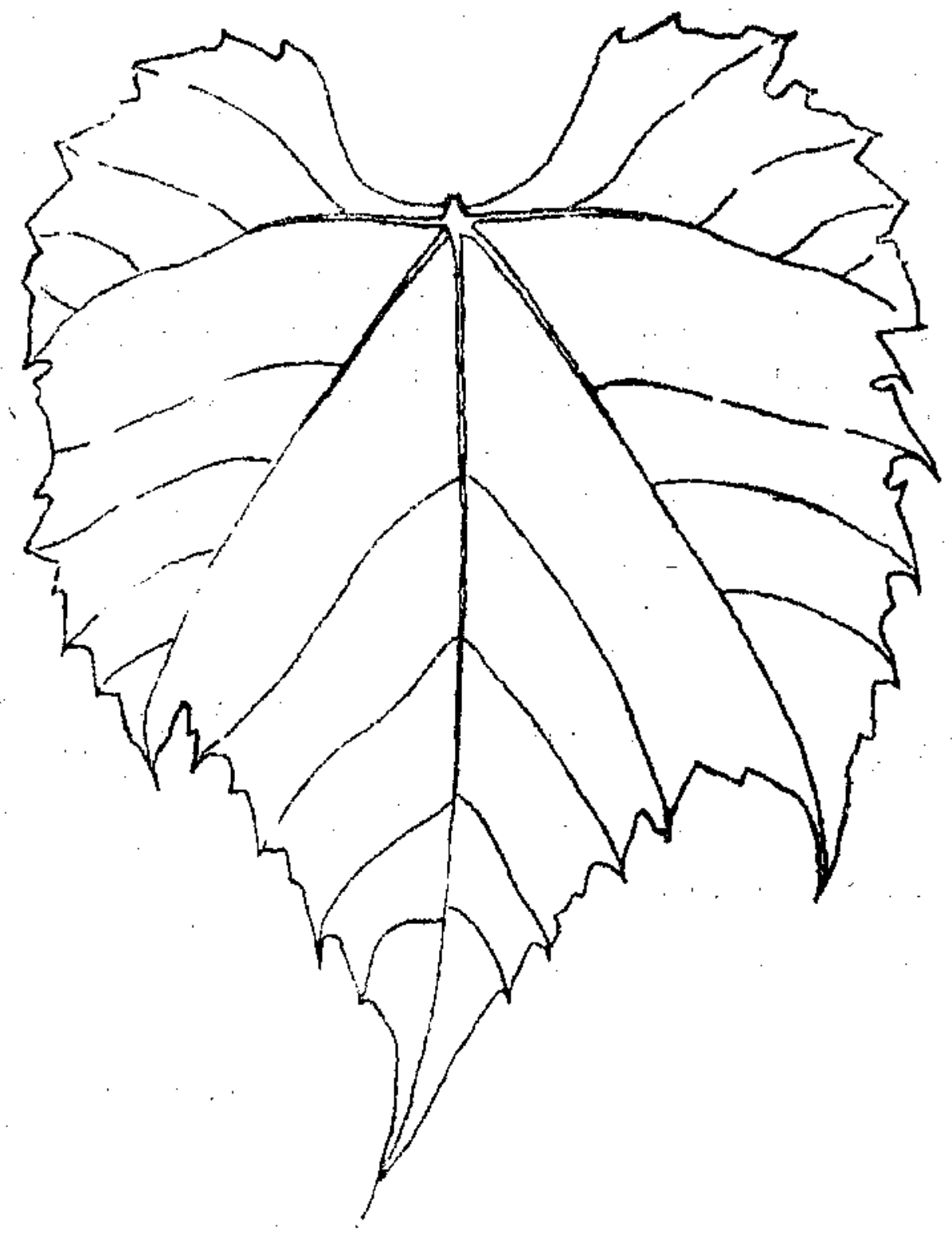

Sl. $3-44-53$ Malegue

\section{Zákijučak}

Ne smijemo ostati ravnodušni prema načinima odabiranja podloga, kaje se i u drugoj obnovi vinograda cesto obavlja na način kao pred tridesetak godina. Nova vromena omogućuju nam da se lakše koristimo naučnim dostignućima i praktičnim iskustvima i na polju naprednog vinogradarstva.

Prvi je zadatak da se sto prije podigne uzorni lozni rasadnik najboljih savremenih podloga, sa prvoklasnim odabranim rasadnickim mat terijalom (iz uvoza Montpellier), koji bi služio kao matiěni ishodni materijal; sa svim rasadniðkim proizvodima, a istodobno bi služlo i kao oglednt objekat za ispitivanje podloga na razne faktore. Ujedno, za osi- 
guranje najboljih kalem grančica u ovom nasadu, treba pơdici i odjeljenje najboljih hercegovačkih sorata loza, po mogućnosti iz klonalne selekcije.

U tom novom loznom rasadniku (od oko 10 hektara), koji treba podići na posve novom i nezaraženom zemljištu, uzgajale bi se sljedeće podloge (27):

I Berlandieri $\times$ Rupestris Richter $110(50 \%)$, mjesto dosadasnje Rupestrise du I.ot.

If Riparia $\times$ Berlandieri 161 49 Couderc $(20 \% / 1)$, mjesto dosadašnjih Berlandieri $\times$ Riparia Kober 5 BB i Teleki 8 B.

III Cordifolia-Rupestris $X$ Riparia Grande Glabre 44-53 Valegue (20\%) mjesto dosadašnjih: Riparia $\times$ Rupestris Schwartzmann i Aramon $\times$ Rupestris Ganzin 1.

Mjesto ove potonje: (Araman $\times$ Rupestris Ganzin 1), eventualno:

IV Berlandieri $\times$ Aramon-Rupestris Ganzin 150-15 Malegue.

V Chasselas $\times$ Bertandieri $41 \mathrm{~B}(9 \%)$ za najvapnenija tla.

VI Solonis $\times$ Riparia 1616 Coudere za zaslanjena tla.

Sa ove tri osnovne i tri fakultativne savremeno najbolje podloge može se zadovoljiti ne samo svako vinogradarsko stanište u vinorodnol Hercegovini (koliko u pogledu kvalitetne toliko i kvantitetne proizvodnje vina, stonog grožđa i ouhvica), nego također i potrebe cijeloga Jadranskog vinogradarskog rejona (od Soče do Bojane).

\section{R S U U}

\section{dONTRIBUTION A L'ETUDE DES PORTE-GREFEES EN HERZEGOVINE}

Dans cet aperçu spécial l'auteur a passé en revue critique la situation des porte-grefies en vit.cutture de l'Herzegovine. Il a undique les defaits dans le choix des porte-greffes à propos do lia premiène reconstitution du vignoble qui a été faite après la premlère guerre mondiale.

Pour la deuxième reconstitution du vignoble qui est en perspective l'auteur recommande l'assortiment des porte-greffes qu'il a fait en vertu de ses propres expériances et d'expériances et résultats qu'on a obtenus à l'étranger. Dans le cholx des porte-greffes l'auteur a surtout tenu compte du facteur de la sécheresse qui est tout fréquante en Fierzégovine et de la terre calcalre et maigre dans cette partie du rayon adriatique du vignoble, comme aussil de l'apparition de la dégénérescence infectieuse de la vigne.

A cet effet l'auteur a recommandé trois porte-greffes fondamentales et trois facultatives.

Comme fondamentales: Berlandier $\times$ Rupestriss Rtchter 110

Riparia $\times$ Berlandiert $161-49$ C.

44-58. Malegue.

Comme facultatives: $150-15$ Malegue.

41 B; M. \&. G.

$1616 \mathrm{C}$. 
INDEKS APROKSIMATIVNE PRILAgODENONTI PODLOGA

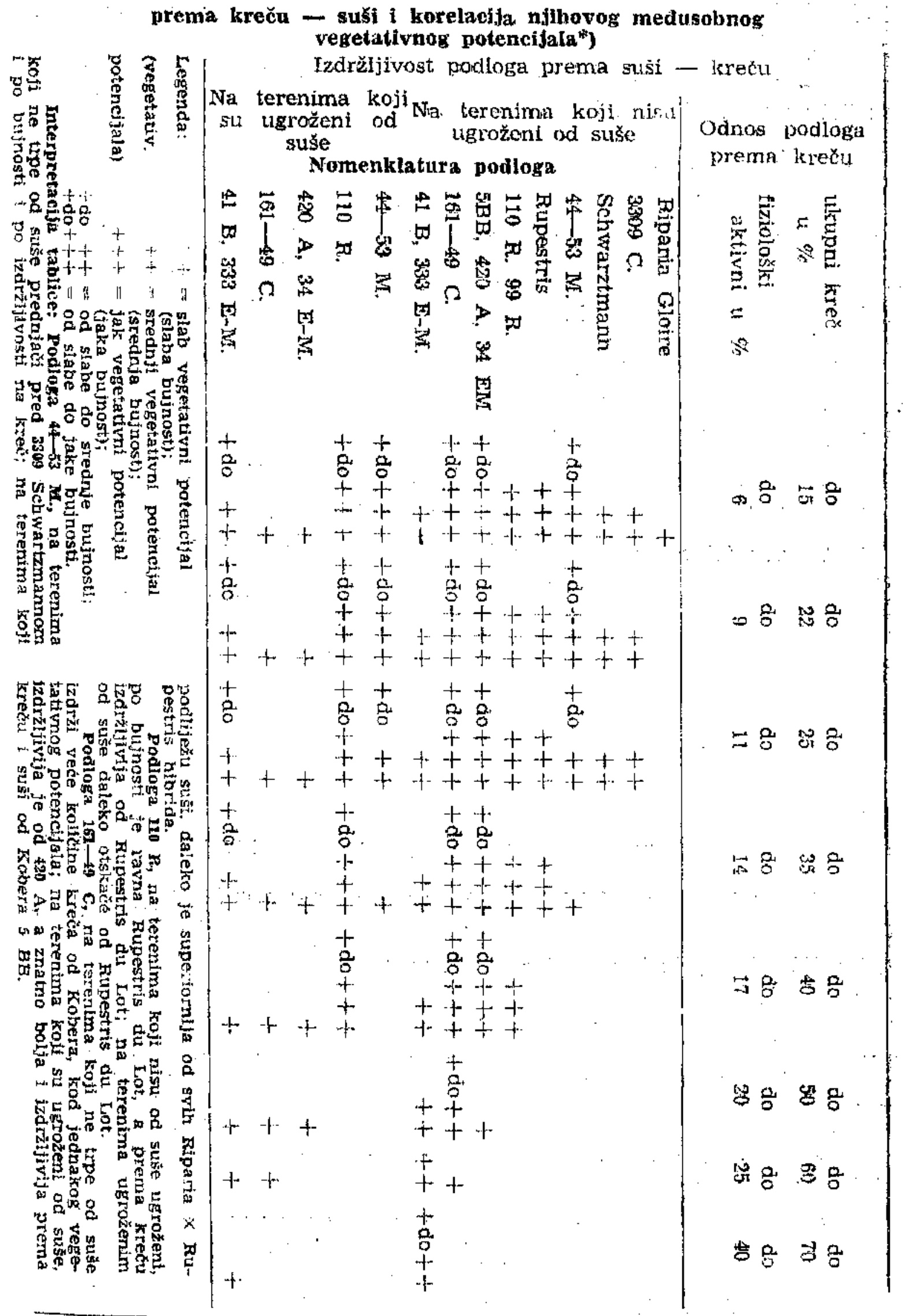

*) Sema tablice po Galet-u (P): Précis D'Ampelographie pratique, Montpellier, 1952.

Dopuna tablice $i$ interpretacija podataka: Cecuk $\mathbf{S}$. 


\section{LT T R ATURA}

1. Gračanin M.: Da li je propadanje loze na podlozi Aramon $x$ Rupestris Ganzin I ediafski Lvjetovano?

2. Ravaz L.: Les vignes americaines, Port-grefles et producteurs directs, Paris et Montpellier 1902 .

3. Branas J. - Bernon G. - Lovadoux J.: Elemerts de viticulculture generale, Montpellier; 1946 .

4. Oliviero Oliviexi: Vitieni porta-innesti americani, Mbilano, 1936.

5. Turkovic Z.: Podloge vinove Inze, Polj. Nakladni Zavad, Zagreb 1951.

8. Siebenunddreissigste Denkscinxift uber die Beläanplung der Reblaus 1015-1023 und 19\%. Bearbeitet in dev Biologischen Reichsanstalt Berilin, 1925:

7. Cosmo J. - Piel: G.: Ampelopatia da non trascuraye. La degeneram zione infettiva, pag. 39, No. 2 febbrio, ConegJiano, 1955.

4. Mateković S: O razvojil upotrebe americkin podloga u vinogiadarstvu Vojvodine, Vojvodanski poljoprivxednlik, god. IV. br. 9, Novi Sad 1948.

9. Su pica M.: lzbor podloga za sadnju nasih vinogrado la Baspi i Hercegovini. Poljoprivredni Pregled br. 5 Sarajevo, 1954.

10. Supica M.: Koja je podioga najbolja u vinogıadarstwu? Poljoprivredni Pregled br, 2, Sarajevo, 1362.

11. Cè̃ uk S.: Propadanje vinograda. (Slike: slabi afinitet) Primorski zadrugar br. 3', Split, 1939.

3.․ Ožanic S.: Nekoja iskustva o amexikanskoj lozi, Ladar, 1907.

13. K a $\mathrm{y}$ ij c L $\mathrm{cj}$ : Lstraživanje tla i svojstva loze $z$ potrebe našeg vinogradar. stva (Ampelopedološka kartiranja) Gospodarski Glasnik by. B-7, Zaereb. 1944 .

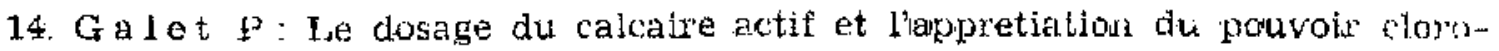
sant des sols. Progres agricule et viticole. Novembre 1951 Montpellien.

15. IV a de $\mathrm{r}$.: Die Sortemwahl der Amerikanerreben bei Herstellung der Weingärter, Handbuch des Weinbaues, Berlin 1923.

10. Haviz L.: Porte-grefles resistant au salant (Prog. Agr. et Viticoie, 1923-2, 1927--2, $192 \%-2)$ Montpellier.

17. Boubals D. - H u gin F.: Un deperissement do la vigne en relation avec lia secheresse, Montpellier, 1950.

18. Ravez I.: Les porte-greifes des terrains hurnides; Progrès agricole et vilicole, 19:22-2, Montpellier.

19. Nedelðev N.: Ampelograffja, Solija, 1938.

20. Compte $R$ endu: Degenerescence infectieuse de la vigne. Session Officielle Pleniere du Comite de L. O. 1. V. Paris, Septembre 1954.

21. G \& let P.: Precis D'Ampelographie Pratique, Montpellier 1952.

22. Jelask a M.: Osnovi vinogradarstva na Primorju, Zagreb, 1854.

23. Bulletin de lotice International du Vin, Paris fevrler 1535. 
24. Dal m asso G.: Viticoltura moderna, Milano, 1947.

25. Branas J.: Sur le 101-49 C. Progrès agnicole et viticole, Montpellier 1946.

26. Branas J.: Folletage et $161-49$ C. Progrès agricole et viticole No $25-26$. juin, Montpellier 1955.

27. Cecuk S.: Court - Nouè ou Dégénérescence Infectueuse de la vigne en Yougoslavie. Progres Agricole et Viticole No, 40,41, 42, 43 , Montpe!lier, 1955. 